\title{
T-cell responses associated with resistance to Leishmania infection in individuals from endemic areas for Leishmania (Viannia) braziliensis
}

\author{
Rita C Bittar, Ricardo S Nogueira, Ricardo Vieira-Gonçalves, Vanessa Pinho-Ribeiro, \\ Marise S Mattos*, Manoel Paes Oliveira-Neto*, Sergio G Coutinho, Alda M Da-Cruz/ ${ }^{+}$
}

Laboratório de Imunoparasitologia, Departamento de Imunologia, Instituto Oswaldo Cruz-Fiocruz, Av. Brasil 4365, $21040-900$ Rio de Janeiro, RJ, Brasil *Instituto de Pesquisa Clínica Evandro Chagas-Fiocruz, Rio de Janeiro, RJ, Brasil

Subclinical or asymptomatic infection is documented in individuals living in endemic areas for leishmaniasis suggesting that the development of an appropriate immune response can control parasite replication and maintain tissue integrity. A low morbidity indicates that intrinsic factors could favor resistance to Leishmania infection. Herein, leishmanial T-cell responses induced in subjects with low susceptibility to leishmaniasis as asymptomatic subjects were compared to those observed in cured cutaneous leishmaniasis (CCL) patients, who controlled the disease after antimonial therapy. All of them have shown maintenance of specific long-term immune responses characterized by expansion of higher proportions of $\mathrm{CD}^{+}$as compared to $\mathrm{CD} 8^{+}$Leishmania reactive T-lymphocytes. Asymptomatic subjects had lower indexes of in vitro Leishmania induced lymphoproliferative responses and interferon-gamma (IFN- $\gamma$ ) production in comparison to CCL patients. On the other hand, interleukin (IL-10) production was much higher in asymptomatics than in CCL, while no differences in IL-5 levels were found. In conclusion, long lived T-cell responses achieved by asymptomatic individuals differed from those who had developed symptomatic leishmaniasis in terms of intensity of lymphocyte activation (proliferation or IFN- $\gamma$ ) and regulatory mechanisms (IL-10). The absence of the disease in asymptomatics could be explained by their intrinsic ability to create a balance between immunoregulatory (IL-10) and effector cytokines (IFN- $\gamma$ ), leading to parasite destruction without producing skin tissue damage. The establishment of profiles of cell-mediated immune responses associated with resistance against Leishmania infection is likely to make new inroads into understanding the long-lived immune protection against the disease.

Key words: asymptomatic infection - Leishmania (Viannia) braziliensis - cured leishmaniasis - cytokines - T-cell subsets long term immunity

American tegumentary leishmaniasis (ATL) is caused by protozoans of the genus Leishmania. In Brazil the disease is endemic all over the country, in which about 35,000 new cases are notified by year (MS/SVS 2002), most of them caused by L. (Viannia) braziliensis (Grimaldi Jr \& MacMahon-Pratt 1991). The spectrum of the clinical presentation ranges from self-healing or benign cutaneous lesions to more severe forms, such as disseminated lesions or mucosal involvement (Da-Cruz \& Pirmez 2005).

Studies conducted in mice and humans have unequivocally shown that a major T-cell driven component underlies the establishment of acquired immunity and protection against re-infection (Coutinho et al. 1996, Louis et al. 1998, Bosque et al. 2000). Cytokines such as interferon-gamma (IFN- $\gamma$ ) and tumor necrosis factor-

Financial support: Faperj (grant number E-26/ 170.844/2003), Papes III/Fiocruz, Instituto Oswaldo Cruz/internal funds, Economic European Community (grant \# TS3 CT 94.0319)

${ }^{+}$Corresponding author: alda@ioc.fiocruz.br

RVG, VPR are CNPq sponsors. AMC is a CNPq research fellow.

Received 22 February 2007

Accepted 28 May 2007 alpha (TNF- $\alpha$ ) activate macrophages for killing parasites, while interleukin (IL)-4, IL-5, IL-10, and transforming grow factor-beta (TGF- $\beta$ ) favor intracellular parasite growth (Louis et al. 1998, Scott et al. 2004). In addition, IL-10 production by $\mathrm{CD} 4{ }^{+} \mathrm{CD} 25^{+} \mathrm{T}$-cells is required for maintenance of Leishmania after cure, which in turn preserves an adaptive immunity to L. (Leishmania) major (Belkaid et al. 2002).

The majority of ATL patients develop cutaneous leishmaniasis (CL) (Oliveira-Neto et al. 2000), but occurrence of subclinical or asymptomatic infection strongly suggests that populations at risk could be exposed to the parasite and acquire the infection without developing the disease (Marzochi et al. 1980, Souza et al. 1992, Davies et al. 1995, Bosque et al. 2000). In Rio de Janeiro, it is estimated that 8.9 to $39.4 \%$ of inhabitants living in endemic areas for leishmaniasis have a positive Montenegro skin test (MST), indicating the development of a delayed type hypersensitivity to leishmanial antigens after parasite infection (Marzochi et al. 1980, Souza et al. 1992). Individuals who have acquired Leishmania infection usually show expansion of parasite specific lymphocytes, and long-term T-cell responses are maintained even after clinical cure. Long-term immunity in cured leishmaniasis patients is characterized by higher proportions of $L b$-reactive $\mathrm{CD}^{+}$than of $\mathrm{CD}^{+} \mathrm{T}$-cells, maintenance of IFN- $\gamma$ and low levels of IL-5 (Da-Cruz et al. 2002). On the other hand, the occurrence of subclinical 
infection or asymptomatic individuals in endemic areas suggests that infected individuals can control Leishmania replication preventing the development of the disease. In this connection, the maintenance of Leishmania specific long-term immunity in asymptomatic subjects reinforces the idea that frequent parasite stimuli can confer protection against Leishmania re-infection or reactivation in individuals from endemic areas (Bosque et al. 2000, Follador et al. 2002).

In asymptomatic individuals low levels of IFN- $\gamma$ and TNF- $\alpha$ are induced contrasting with the strong production of these cytokines observed during active leishmaniasis (Follador et al. 2002). It should be pointed out that enough amounts of inflammatory cytokines can be sufficient to control parasite infection, but regulatory mechanisms underlying resistance against leishmaniasis need to be better clarified.

In this study, leishmanial T-cell responses induced in asymptomatic subjects were compared to those observed in clinically cured patients. Our aim was to establish profiles of T-cell phenotypes and cytokines associated with resistance to leishmaniasis. We believe that such profiles can provide a better insight into the immunological mechanisms associated with protection against the disease.

\section{SUBJECTS, MATERIALS, AND METHODS}

Studied population - Twenty-eight individuals from endemic areas for $L$. (V.) braziliensis (Lb) infection in the state of Rio de Janeiro were studied. The subjects were divided into two groups: 11 asymptomatic subjects ( 4 males and 7 females, mean age $\pm \mathrm{SD}=40.2 \pm 21$ years, median $=37$ years), 17 cured CL patients (CCL) evaluated 1-17 years after the end of therapy ( 8 males and 9 females, mean age $\pm \mathrm{SD}=42.5 \pm 14.2$ years, median $=40$ years). Asymptomatic individuals had no clinical past history of skin ulcer suggestive of leishmaniasis. Subclinical infection was determined by in vitro evidence of induction of cellular responses to leishmanial antigens (lymphocyte activation-proliferation and/or IFN- $\gamma$ production). CCL patients were diagnosed with leishmaniasis confirmed by clinical, parasitological, and/ or immunological tests and achieved clinical cure after successful antimonial therapy (Da-Cruz et al. 2002). The MST was performed soon after blood collection for in vitro immunological studies, in order to avoid a possible influence on parasite specific in vitro assays, due to the induction of local immune response. The MST was positive in six out of nine CCL patients $(18.2 \pm 8.7 \mathrm{~mm}$, median $=16.6 \mathrm{~mm}, \mathrm{n}=6$ ). Two asymptomatic subjects were evaluated and the results of the cutaneous test were $15 \mathrm{~mm}$ and 5 $\mathrm{mm}$ of skin enduration.

Sera from asymptomatic subjects or cured patients were non-reactive for the presence of Leishmania specific IgM and IgG immunoglobulins by indirect immunofluorescence. This study was approved by the Ethic Committee of the Fundação Oswaldo Cruz. Informed consent was obtained from all individuals.

Lymphocyte proliferative response (LPR) assays Peripheral blood mononuclear cells (PBMC) were used in LPR assays as previously described (Da-Cruz et al. 1994). Briefly, PBMC were purified over a Ficoll-
Hypaque gradient (Sigma Chemical Co., St. Louis, MO, US), seeded in 96-well round-bottom plates $\left(3 \times 10^{5} \%\right.$ well, Nunc, Roskilde, Denmark) in a final volume of 200 $\mu \mathrm{l} /$ well. Cultures were incubated for 5 days at $37^{\circ} \mathrm{C}$ in humidified atmosphere of $5 \% \mathrm{CO}_{2}$ in air, in the presence of Leishmania antigens ( $L b-\mathrm{Ag}$ ), or mitogen (Concanavalin A, $4 \mu \mathrm{g}$ per well, Sigma) or medium alone as control. Disrupted promastigotes of $L$. $(V$.) braziliensis (MHOM/BR/75/M2903) were added at the concentration of $10 \mu \mathrm{g} / \mathrm{well}$ (equivalent of $10^{6}$ parasites). Sixteen hours before harvesting, $1 \mu \mathrm{Ci}$ of $\left[{ }^{3} \mathrm{H}\right]$ thymidine (Amersham International, Amersham, UK) was added to wells. Radioactivity uptake was measured in a scintillation beta counter (1600 CA, Packard Instrumental Co., Downers Grove, IL, US). Results were expressed as stimulation index (SI) defined as counts per minute (cpm) mean in wells containing antigen or mitogen divided by background (mean counts in non-stimulated wells). Indexes equal to or higher than 2.5 were considered positive.

Phenotypic analysis - For obtaining leishmanial antigen-reactive T-cells, PBMC $\left(3 \times 10^{6}\right.$ per well $)$ were in vitro cultured in 24-well flat-bottomed plates (Nunc) in the presence of the equivalent of $5 \times 10^{6}$ disrupted $L b$ promastigotes under conditions previously described. After five days in culture, cells were harvested and washed, and then blast cells were separated by centrifugation over discontinuous Percoll gradient (Sigma). For phenotypic analysis, $L b$-reactive blast T-cells were incubated in the presence of $5 \mu \mathrm{l}$ of monoclonal antibodies (Coulter Corporation, Hialeah, FL, US) for $\mathrm{CD}^{+}$ (CD3-RD1), CD4 ${ }^{+}$(T4-FITC), and CD8 ${ }^{+}$(T8-RD1). After incubation, the cells were washed three times and resuspended in a fixing solution containing $1 \%$ paraformaldehyde in PBS prior to flow cytometric analysis. Blast cells were defined by forward and side-scatter gating. Each sample was run and data was analyzed with EXPO32 $2^{\mathrm{TM}}$ software in an EPICS ALTRA flow cytometer (Beckman-Coulter, Miami, US). Each culture's supernatant was collected on day 3 to test IL-5 and IL-10 concentrations and on day 5 to test IFN- $\gamma$ concentration. Supernatants were stored at $-20^{\circ} \mathrm{C}$ until use.

Cytokine measurement - Cytokine assays were performed by enzyme-linked immunosorbent assay (ELISA). Monoclonal antibodies and recombinant cytokines were purchased from BD Biosciences Pharmingen, San Diego, CA, US. All samples were tested in duplicate and compared to standard curves to determine the cytokine concentration. The procedures were performed according to the manufacture's instructions, and the concentration was analyzed using SOFTmax ${ }^{\circledR}$ PRO 4.0 program (Life Sciences Edition, Molecular Devices Corporation, US). Results were expressed in picograms per milliliter. The minimum cytokine levels detected were $62.5 \mathrm{pg} / \mathrm{ml}$ for IFN $\gamma, 31.2 \mathrm{pg} / \mathrm{ml}$ for IL-10, and $15.6 \mathrm{pg} / \mathrm{ml}$ for IL-5.

Statistical analysis - The Mann-Whitney test was used to compare the results for three groups. The analysis was performed by GraphPad Instat ${ }^{\mathrm{TM}} \mathrm{V} 2.04$ (GraphPad ${ }^{\mathrm{TM}}$ Software, San Diego, CA, US) and SPSS (8.0 for Windows) softwares. The results were expressed as mean \pm standard deviation and/or median. 


\section{RESULTS}

$L P R$ of PBMC stimulated in vitro with $\mathrm{Lb}-\mathrm{Ag}$ - The LPR induced by $L b-\mathrm{Ag}$ was positive (stimulation index $\geq 2.5$ ) in all CCL patients ( $\mathrm{SI}=15.7 \pm 14.7$, median $=$ $10.4, \mathrm{n}=17)$ and asymptomatic subjects $(\mathrm{SI}=9.3 \pm 9.8$, median $=6.2, \mathrm{n}=11)($ Fig. 1A). CCL patients presented significantly higher SI when compared to asymptomatic individuals $(\mathrm{p}=0.025)$.
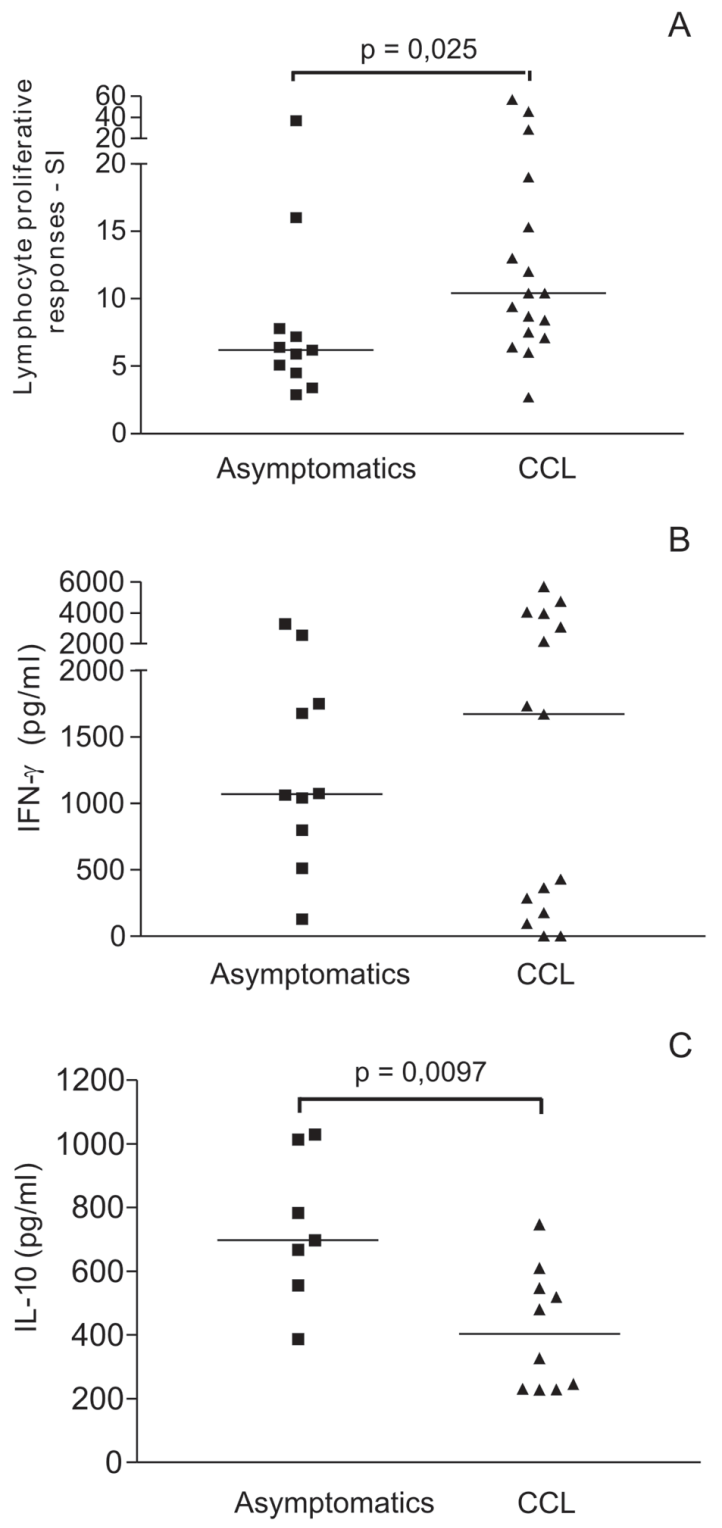

Fig. 1: lymphocyte proliferative responses (A) and cytokine production $[\mathrm{B}-$ interferon- $\gamma(\mathrm{IFN}-\gamma)$ and $\mathrm{C}$ - interleukin-10 (IL-10)] in asymptomatic subjects and cured cutaneous leishmaniasis (CCL) patients. Peripheral blood mononuclear cells were in vitro stimulated with Leishmania (Viannia) braziliensis antigens as described in the Materials and Methods. Results of lymphocyte proliferative responses are expressed as stimulation indexes (SI). The cytokine production in the supernatants of each culture was determined by ELISA. Each point represents one patient. The horizontal bars represent the median values for each group.
Phenotypic characterization of Lb-reactive T-cells - T lymphocytes preferentially proliferated in response to leishmanial antigens: asymptomatic individuals $\left(\mathrm{T} \mathrm{CD}^{+}=78 \pm 14.7 \%\right.$, median $\left.=78 \%, \mathrm{n}=02\right)$ and $\mathrm{CCL}$ patients $\left(\mathrm{T} \mathrm{CD}^{+}=50 \pm 21.7 \%\right.$, median $=49.4 \%$, $\mathrm{n}=14$ ). A clear preferential induction of $\mathrm{CD}^{+}$over $\mathrm{CD}^{+} \mathrm{T}$ cells was observed in all analyzed groups: asymptomatic individuals $-\mathrm{T} \mathrm{CD}^{+}=43.8 \pm 19.8 \%$ (median $=47.6 \%, \mathrm{n}=10)$ and $\mathrm{T} \mathrm{CD} 8^{+}=37.6 \pm 13 \%(\mathrm{me}-$ dian $=35.3 \%, \mathrm{n}=10) ; \mathrm{CCL}$ patients $-\mathrm{T} \mathrm{CD} 4^{+}=29.5 \pm$ $20 \%($ median $=23.2 \%, \mathrm{n}=14)$, and $\mathrm{T} \mathrm{CD} 8^{+}=13.8 \pm$ $6.7 \%($ median $=11.5 \%, \mathrm{n}=14)$. Higher percentages of $\mathrm{CD}^{+}(\mathrm{p}=0.02)$ and $\mathrm{CD} 8^{+} \mathrm{T}$-cells $(\mathrm{p}<0.0001)$ were observed in asymptomatic individuals as compared to CCL (Fig. 2).

Cytokine production by PBMC stimulated in vitro with $\mathrm{Lb}-\mathrm{Ag}$ - The mean levels of IFN- $\gamma$ in the cell culture supernatants from asymptomatic individuals (1282 $\pm 972 \mathrm{pg} / \mathrm{ml}$, median $=1064 \mathrm{pg} / \mathrm{ml}, \mathrm{n}=11$ ) were lower than those observed CCL patients $(1975 \pm 2054 \mathrm{pg} / \mathrm{ml}$, median $=1670 \mathrm{pg} / \mathrm{ml}, \mathrm{n}=17)(\mathrm{p}>0.05)$. We found that among CCL there were high and low IFN- $\gamma$ producers, and this cytokine was not detectable in three patients (Fig. 1B).

In contrast, IL-10 levels were significantly higher for asymptomatic individuals $(733 \pm 233 \mathrm{pg} / \mathrm{ml}$, median $=$ $698 \mathrm{pg} / \mathrm{ml}, \mathrm{n}=7)$ in comparison to CCL patients $(416 \pm 188 \mathrm{pg} / \mathrm{ml}$, median $=403 \mathrm{pg} / \mathrm{ml}, \mathrm{n}=10)(\mathrm{p}=0.009)$.

IL-5 production was observed in CCL patients (91.3 $\pm 71.3 \mathrm{pg} / \mathrm{ml}$, median $=42 \mathrm{pg} / \mathrm{ml}, \mathrm{n}=11)$, but this cytokine was only detected in two out of nine asymptomatic subjects $(45.2 \pm 17.8 \mathrm{pg} / \mathrm{ml})$.

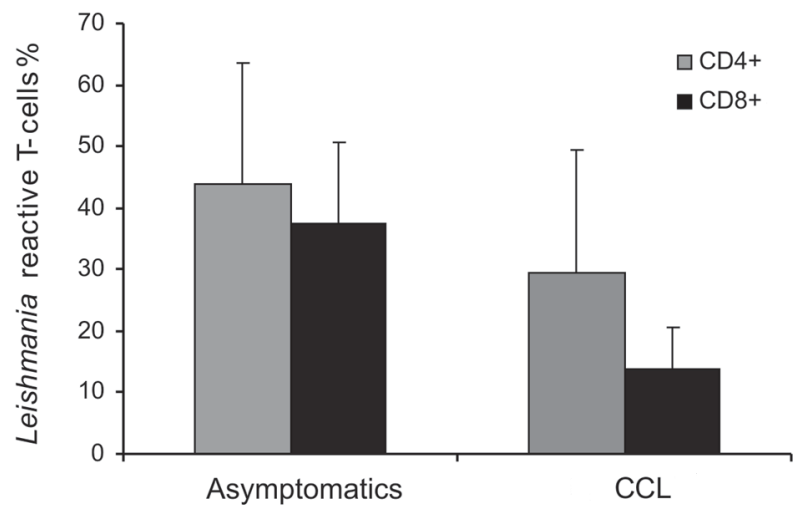

Fig. 2: percentage of Leishmania reactive $\mathrm{CD} 4^{+}$and $\mathrm{CD} 8^{+}$proliferating T-cells in asymptomatic subjects and cured cutaneous leishmaniasis (CCL) patients. Peripheral blood mononuclear cells were in vitro stimulated by Leishmania (Viannia) braziliensis antigens. After five days in culture, the blast cells were harvested and separated over a Percoll gradient. The blast cells were stained with anti-CD4 or -CD8 monoclonal antibodies for flow cytometric analysis. The results are expressed as mean \pm standard deviations. 


\section{DISCUSSION}

The main factors that determine who will develop leishmaniasis are still unknown. However, the establishment of cellular mediated immune (CMI) responses, especially regulation of cytokine network involved in anti-leishmanial immunity, is likely to be associated with clinical outcome (Coutinho et al. 1996, Rocha et al. 1999, Toledo et al. 2001). According to our results, the profiles of these CMI responses detected in subjects resistant to or recovered from leishmaniasis may provide a better understanding of the long-lived immune protection to the disease.

The individuals included in this study were potentially exposed to Leishmania infection since they came from endemic areas with epidemiological evidences of parasite transmission (Oliveira-Neto et al. 2000). Evidence for subclinical infection was assessed by LPR and/or IFN- $\gamma$ production as well as by MST. These tests have proven to be valuable in detecting subclinical infection in endemic areas for $L$. (L.) major or $L$. (V.) braziliensis infection (Marzochi et al. 1980, Souza et al. 1992, Sassi et al. 1999, Follador et al. 2002) since they are able to measure CMI induced by leishmanial antigens. Our results showed that the intensity of lymphocyte proliferation differed between the groups of Leishmania exposed individuals. Clinically cured patients presented significantly higher LPR indexes than those for asymptomatic individuals, similar to the observation on subclinical subjects from endemic areas of Bahia (Follador et al. 2002). Thus, our data point to the hypothesis that intensity of exposition to parasite antigens has a positive influence on the induction of the CMI. Hence, the degree of antigen-specific T-cell expansion in the peripheral blood can be a consequence of parasite load during the infection. It can be also associated with the means whereby these antigens are being recognized by the host $\mathrm{T}$ cells and how these cells are activated (Coutinho et al. 1996). Thus, the higher the number of clones of specific T-cells expanded the higher the number of clones found in the periphery. It can explain the increased lymphocyte proliferation indexes observed in group CCL (who developed leishmaniasis years earlier) than asymptomatic individuals. Moreover, it is supposed that the frequent boosters provoked by endogenous parasites that may persist in lymphoid tissues (Barral et al. 1995) or scars (Schubach et al. 1998) as well as exogenous re-infections allow the establishment of a persistent pool of circulating experienced T-cells. This is in accordance with the idea that maintenance of T-cell mediated immunity requires the presence of an antigen (Kündig et al. 1996, Mendez et al. 2004), although it has been recently shown that a pool of memory T-cell can persist in the absence of antigen stimulation (Zaph et al. 2004).

The T-cell mediated immunological profile observed in subjects controlling the infection may represent a sustained immune response associated with protection against relapses or re-infections. Both $\mathrm{CD}^{+}$and $\mathrm{CD} 8^{+}$ $\mathrm{T}$ subpopulations were expanded upon leishmanial stimuli in CCL or asymptomatic individuals suggesting that these two subsets are required for protection (Herath et al. 2003, Rocha \& Tachot 2004).
$\mathrm{CD}^{+}$Leishmania reactive T-cells where preferentially expanded in all asymptomatic individuals confirming our previous results of higher $\mathrm{CD} 4^{+} / \mathrm{CD} 8^{+}$proportions associated with long term immunity in clinically CCL patients (Da-Cruz et al. 2002). Also it has been hypothesized that $\mathrm{CD} 8^{+} \mathrm{T}$ cells expanded soon after the end of therapy (Da-Cruz et al. 1994, Toledo et al. 2001) could play a crucial role for the early control of the infection (Belkaid et al. 2002). After exerting their effector functions (cytotoxic or IFN- $\gamma$ production) (Brodskyn et al. 1997) only part of these CD $8^{+}$T-cells should be maintained in a pool of central memory cells (Tanchot et al. 1997, Wherry et al. 2003, Rocha \& Tanchot 2004). This fact can explain the lower proportions of $\mathrm{CD}^{+}$ T-cells observed in the majority of asymptomatic or cured individuals. Additionally, it is expected that these low proportions of CD8+ T-cells could be re-expanded under parasite stimuli, and maintain the infection under control.

Previous reports have addressed the requirements for generation of $\mathrm{CD} 8^{+}$memory cells (Hamann et al. 1999, Wherry et al. 2002), but little is known about the establishment of long lived CD4 ${ }^{+}$T-cells (Gollob et al. 2005). Thus, it was shown that at least two distinct subpopulations of $\mathrm{CD}^{+}{ }^{+} \mathrm{T}$-cells develop after resolution of experimental $L$. (L.) major infection, but only one requires the presence of the parasite (Wherry et al. 2002, Zaph et al. 2004, Gollob et al. 2005). In humans, it is difficult to determine whether or not long life immunity is dependent on the persistence of parasite in tissues, since they are frequently exposed to new infections in endemic areas.

Cytokines such as IFN- $\gamma$ and IL-10 were detected in all groups studied irrespective of clinical form. No significant difference in IL-5 production was detected among asymptomatic and CCL patients. Although the cytokine cell sources were not determined, $\mathrm{CD} 4^{+} \mathrm{T}$ lymphocytes are considered the main producers of IFN- $\gamma$ in mice (Belkaid et al. 2001) and in humans CL (Bottrel et al. 2001). Differences in terms of IL-10/IFN- $\gamma$ balance were observed in the studied groups. Asymptomatic individuals produced more IL-10 than cured patients. Conversely, the highest levels of IFN- $\gamma$ were shown in cured patients although these levels were not statistically different when compared to asymptomatic subjects. Therefore, IL10/IFN- $\gamma$ ratio was directly related to the ability to control the infection, being higher among asymptomatics, who are considered resistant to the parasite. Although IL-10 can favor the progression of the disease in the early phase of leishmaniasis, depending on the counter balance exerted by IFN- $\gamma$, cure can be achieved due to its effector functions on parasitized macrophages (Rocha et al. 1999, Bosque et al. 2000). Moreover, our results strengthen the idea that the intrinsic ability to produce IL-10 in response to Leishmania infection can be a key factor in avoiding a possible harmful effect of IFN- $\gamma$, exerting an important function on regulating inflammatory responses necessary for infection control (Rocha et al. 1999, Belkaid et al. 2001, Bacellar et al. 2002, Gomes-Silva et al. 2007).

Overall, our results indicate that individuals, who apparently controlled Leishmania infection, either spontaneously or after therapy, maintain a specific long-term 
immune response. The ability to control the infection and parasite replication without progressing to clinically apparent disease can be a consequence of a very wellmodulated immunity. In this process an expansion of suitable clones of effector $\mathrm{CD}^{+}{ }^{+}$and $\mathrm{CD} 8^{+} \mathrm{T}-$-cell subsets together with a well balanced IL-10 and IFN- $\gamma$ production should be expected. Absence of disease in asymptomatic individuals could be explained by their intrinsic capacity to produce IL-10 in suitable levels for maintenance of an appropriate balance between immunoregulatory and effector functions. We argue that the induction of a well-regulated immune response able to destroy the parasite without producing skin tissue damage should be considered a challenge to be met in the attempt to develop a vaccine candidate for leishmaniasis.

\section{ACKNOWLEDGMENTS}

To Dr Nancy Saravia for her valuable suggestions. To Dr Alvaro Bertho for flow cytometry analysis, to Dr Wilson JS Souza for immunofluorescence assays, and to Ms Rosangela Pellegrino for secretarial assistance. To Dr Pedro Cabello for helping with the statistical analyses.

\section{REFERENCES}

Bacellar O, Lessa H, Schriefer A, Machado P, Ribeiro de Jesus A, Dutra W, Gollob KJ, Carvalho EM 2002. Up-regulation of Th1-type responses in mucosal leishmaniasis patients. Infect Immun 70: 6734-6740.

Barral A, Guerreiro J, Bomfim G, Correia D, Barral-Netto M, Carvalho EM 1995. Lymphadenopathy as the first sign of human cutaneous infection by Leishmania braziliensis. Am J Trop Med Hyg 53: 256-259.

Belkaid Y, Hoffmann KF, Mendez S, Kamhawi S, Udey MC, Wynn TA, Sacks DL 2001. The role of interleukin (IL)-10 in the persistence of Leishmania major in the skin after healing and the therapeutic potential of anti-IL-10 receptor antibody for sterile cure. J Exp Med 194: 1497-1506.

Belkaid Y, Piccirillo CA, Mendez S, Shevach EM, Sacks DL 2002. $\mathrm{CD}^{+} \mathrm{CD}_{25}{ }^{+}$regulatory $\mathrm{T}$ cells control Leishmania major persistence and immunity. Nature 420: 502-507.

Belkaid Y, Von Stebut E, Mendez S, Lira R, Caler E, Bertholet S, Udey MC, Sacks D 2002. CD8 ${ }^{+} \mathrm{T}$ cells are required for primary immunity in C57BL/6 mice following low-dose, intradermal challenge with Leishmania major. J Immunol 168: 3992-4000.

Bosque F, Saravia NG, Valderrama L, Milon G 2000. Distinct innate and acquired immune responses to Leishmania in putative susceptible and resistant human populations endemically exposed to L. (Viannia) panamensis infection. Scand J Immunol 51: 533-541.

Bottrel RLA, Dutra WO, Martins FA, Gontijo B, Carvalho E, Barral-Neto M, Barral A, Almeida RP, Mayrink W, Locksley R, Gollob KJ 2001. Flow cytometric determination of cellular sources and frequencies of key cytokine-producing lymphocytes directed against recombinant LACK and soluble Leishmania antigen in human cutaneous leishmaniasis. Infect Immun 69: 3232-3239.

Brodskyn CI, Barral A, Boaventura V, Carvalho E, Barral-Netto M 1997. Parasite-driven in vitro human lymphocyte cytotoxicity against autologous infected macrophages from mucosal leishmaniasis. J Immunol 159: 4467-4473.
Coutinho SG, Oliveira MP, Da-Cruz AM, De-Luca PM, Mendonça SCF, Bertho AL, Soong L, McMahon-Pratt D 1996. T-cell responsiveness of American cutaneous leishmaniasis patients to purified Leishmania pifanoi amastigote antigens and Leishmania braziliensis promastigote antigens. Immunologic patterns associated with cure. Exp Parasitol 84: 144-155.

Da-Cruz AM, Pirmez C 2005. Leishmaniose tegumentar americana. In JR Coura, Dinâmica das Doenças Infecciosas e Parasitárias, Guanabara Koogan, Rio de Janeiro, p. 697-712.

Da-Cruz AM, Bittar R, Mattos M, Oliveira-Neto MP, Nogueira R, Pinho-Ribeiro V, Azeredo-Coutinho RB, Coutinho SG 2002. T-cell-mediated immune responses in patients with cutaneous or mucosal leishmaniasis: long-term evaluation after therapy. Clin Diagn Lab Immunol 9: 251-256.

Da-Cruz AM, Conceição-Silva F, Bertho AL, Coutinho SG 1994. Leishmania-reactive $\mathrm{CD}^{+}{ }^{+}$and $\mathrm{CD} 8^{+} \mathrm{T}$ cells associated with cure of human cutaneous leishmaniasis. Infect Immun 62: 2614-2618.

Davies CR, Llanos-Cuentas EA, Pyke SDM, Dye C 1995. Cutaneous leishmaniasis in the Peruvian Andes: an epidemiological study of infection and immunity. Epidemiol Infect 114: 297-318.

Follador I, Araújo C, Bacellar O, Araújo CB, Carvalho LP, Almeida RP, Carvalho EM 2002. Epidemiologic and immunologic findings for the subclinical form of Leishmania braziliensis infection. Clin Infect Dis 34: 54-58.

Gollob KJ, Antonelli LRV, Dutra WO 2005. Insights into CD4 ${ }^{+}$ memory $\mathrm{T}$ cells following Leishmania infection. Trends Parasitol 21: 347-350.

Gomes-Silva A, Bittar RC, Nogueira RS, Amato VS, Mattos MS, Oliveira-Neto MP, Coutinho SG, Da-Cruz AM 2007. Can IFN- $\gamma$ and IL-10 balance be associated with severity of human Leishmania (Viannia) braziliensis infection? Clin Exp Immunol, in press.

Grimaldi Jr G, McMahon-Pratt D 1991. Leishmaniasis and its etiologic agents in the New World: an overview. Prog Clin Parasitol 2: 73-118.

Hamann D, Roos MThLR, Lier van RAW 1999. Faces and phases of human $\mathrm{CD}^{+} \mathrm{T}$ cell development. Immunol Today 20: 177-180.

Herath S, Kropf P, Müller I 2003. Cross-talk between CD8 ${ }^{+}$and $\mathrm{CD}^{+} \mathrm{T}$ cells in experimental cutaneous leishmaniasis: $\mathrm{CD}^{+} \mathrm{T}$ cells are required for optimal IFN- $\gamma$ production by $\mathrm{CD}^{+}{ }^{+} \mathrm{T}$ cells. Parasite Immunol 25: 559-567.

Kündig TM, Bachmann MF, Oehen S, Hoffmann UW, Simard JJ, Kalberer CP, Pircher H, Ohashi PS, Hengartner H, Zinkernagel RM 1996. On the role of antigen in maintaining cytotoxic T-cell memory. Proc Natl Acad Sci USA 93: 9716-9723.

Louis J, Himmelrich H, Parra-Lopez C, Tacchini-Cottier F, Launois P 1998. Regulation of protective immunity against Leishmania major in mice. Curr Opin Immunol 10: 459-464.

Marzochi MCA, Coutinho SG, Sabroza PC, Souza WJS 1980. Reação de imunofluorescência indireta e intradermorreação para leishmaniose tegumentar americana em moradores na área de Jacarepaguá (Rio de Janeiro): estudo comparativo dos resultados observados em 1974 e 1978. Rev Inst Med Trop São Paulo 22: 149-155.

Mendez S, Reckling SK, Piccirillo CA, Sacks D, Belkaid Y 2004. Role for $\mathrm{CD}^{+} \mathrm{CD} 25^{+}$regulatory $\mathrm{T}$ cells in reactivation of 
persistent leishmaniasis and control of concomitant immunity. J Exp Med 200: 201-210.

MS/SVS-Ministério da Saúde/Secretaria de Vigilância em Saúde 2002. Boletim Eletrônico, Ano 2, no 5. Available at: http:// portal.saúde.gov.br/portal/svs; accessed on Jan 31st 2007.

Oliveira-Neto MP, Mattos MS, Perez MA, Da-Cruz AM, Fernandes O, Moreira J, Gonçalves-Costa SC, Brahin LR, Menezes CR, Pirmez C 2000. American tegumentary leishmaniasis (ATL) in Rio de Janeiro State, Brazil: main clinical and epidemiologic characteristics. Int J Dermatol 39: 506-514.

Rocha B, Tanchot C 2004. Towards a cellular definition of $\mathrm{CD}^{+}$ T-cell memory: the role of $\mathrm{CD}^{+} \mathrm{T}$-cell help in $\mathrm{CD} 8^{+} \mathrm{T}$-cell responses. Curr Opin Immunol 16: 259-263.

Rocha PN, Almeida RP, Bacellar O, Ribeiro de Jesus A, Correia Filho D, Cruz Filho A, Barral A, Coffman RL, Carvalho EM 1999. Down-regulation of Th1 type of response in early human American cutaneous leishmaniasis. J Infect Dis 180: 1731-1734.

Sassi A, Louzir H, Salah AB, Mokni M, Osman AB, Dellagi K 1999. Leishmanin skin test, lymphoproliferative responses and cytokine production after symptomatic or asymptomatic Leishmania major infection in Tunisia. Clin Exp Immunol 116: 127-132.

Schubach A, Haddad F, Oliveira-Neto MP, Degrave W, Pirmez C, Grimaldi G, Fernandes O 1998. Detection of Leishmania DNA by the polymerase chain reaction in scars of treated human patients. J Infect Dis 178: 911-914.
Scott P, Artis D, Uzonna J, Zaph C 2004. The development of effector and memory $\mathrm{T}$ cells in cutaneous leishmaniasis: the implications for vaccine development. Immunol Rev 201: 318-338

Souza WJS, Sabroza PC, Santos CS, Souza E, Henrique MF, Coutinho SG 1992. Montenegro skin tests for American cutaneous leishmaniasis carried out on school children in Rio de Janeiro, Brazil: an indicator of transmission risk. Acta Trop 52: 111-119.

Tanchot C, Lemonnier FA, Pérarnau B, Freitas AA, Rocha B 1997. Differential requirements for survival and proliferation of CD8 naïve or memory T cells. Science 276: 2057-2062.

Toledo VPCP, Mayrink W, Gollob KJ, Oliveira MAP, Costa CA, Genaro O, Pinto JA, Afonso LCC 2001. Immunochemotherapy in American cutaneous leishmaniasis: immunological aspects before and after treatment. Mem Inst Oswaldo Cruz. 96: 89-98

Wherry EJ, McElhaugh MJ, Eisenlohr LC 2002. Generation of $\mathrm{CD}^{+} \mathrm{T}$ cell memory in response to low, high, and excessive levels of epitope. J Immunol 168: 4455-4461.

Wherry EJ, Teichgräber V, Becker TC, Masopust D, Kaech SM, Antia R, von Adrian UH, Ahmed R 2003. Lineage relationship and protective immunity of memory CD8 T cell subsets. Nature Immunol 4: 225-234.

Zaph C, Uzonna J, Beverley SM, Scott P 2004. Central memory T cells mediate long-term immunity to Leishmania major in the absence of persistent parasites. Nature Medicine 10: 1104-1110. 